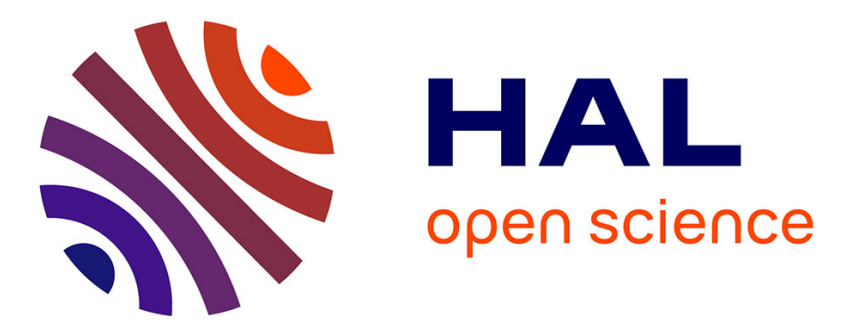

\title{
Sulphur signature in the hydrothermal-vent mussel Bathymodiolus azoricus from the Mid-Atlantic Ridge
}

Audrey M Pruski, Nathalie Rousse, Aline Fiala-Médioni, Jacques Boulègue

\section{To cite this version:}

Audrey M Pruski, Nathalie Rousse, Aline Fiala-Médioni, Jacques Boulègue. Sulphur signature in the hydrothermal-vent mussel Bathymodiolus azoricus from the Mid-Atlantic Ridge. Journal of the Marine Biological Association of the UK, 2002, 82 (3), pp.463-468. 10.1017/S0025315402005726. hal-02908689

\section{HAL Id: hal-02908689 \\ https://hal.sorbonne-universite.fr/hal-02908689}

Submitted on 29 Jul 2020

HAL is a multi-disciplinary open access archive for the deposit and dissemination of scientific research documents, whether they are published or not. The documents may come from teaching and research institutions in France or abroad, or from public or private research centers.
L'archive ouverte pluridisciplinaire $\mathbf{H A L}$, est destinée au dépôt et à la diffusion de documents scientifiques de niveau recherche, publiés ou non, émanant des établissements d'enseignement et de recherche français ou étrangers, des laboratoires publics ou privés. 


\title{
Sulphur signature in the hydrothermal-vent mussel Bathymodiolus azoricus from the Mid-Atlantic Ridge
}

\author{
Audrey Margareth Pruski* $*^{\ddagger}$, Nathalie Rousse ${ }^{\dagger}$, Aline Fiala-Médioni* and Jacques Boulègue ${ }^{\dagger}$ \\ *Observatoire Océanologique de Banyuls, Université Pierre et Marie Curie, UMR CNRS 7621, B.P. 44, 66651 Banyuls-sur-mer cedex, \\ France. ${ }^{\dagger}$ Laboratoire de Géochimie et Métallogénie, Université Pierre et Marie Curie, 4 place Jussieu, 75252 Paris Cedex 05, France. \\ ${ }^{\ddagger}$ Corresponding author, present address: George Deacon Division, Southampton Oceanography Centre, European Way, \\ Southampton SO14 3ZH. Email: a.pruski@hotmail.com
}

\begin{abstract}
The sulphur compound composition of the hydrothermal vent mussel Bathymodiolus azoricus (Bivalvia: Mytilidae) was analysed in order to determine the specific biochemical characteristics of a thiotrophic mode of nutrition. In specimens collected from two contrasting vent-fields on the Mid-Atlantic Ridge (Menez Gwen and Lucky Strike), substantial differences in the sulphur composition were observed between tissues and sampling sites. Total sulphur content was higher for samples from Lucky Strike than for those from Menez Gwen. The amount of elemental sulphur in the gill of B. azoricus was in the same range as values previously reported for the vesicomyid clam Calyptogena phaseoliformis and the lucinid clam Lucinoma annulata. Rings of orthorhombic sulphur or compounds such as polythionates or organopolysulphides excreted in the cytoplasm by the symbionts may account for the large amounts of elemental sulphur evidenced for the first time in an hydrothermal vent mussel. A large proportion of the tissue-sulphur was incorporated into free amino compounds such as taurine, hypotaurine, thiotaurine and cysteine, and in a lesser extent to the tripeptide glutathione. In mantles, sulphur seems to be contained mainly in organic compounds such as proteins, mucopolysaccharides and lipids. However, the occurrence of specific compounds such as thiotaurine and elemental sulphur in gills indicate that in this tissue a large proportion of the sulphur might be involved in specific pathways related to transport, storage and detoxification of sulphide. Moreover, our results suggest a greater reliance on thiotrophy of mussels from Lucky Strike as compared to specimens from Menez Gwen.
\end{abstract}

\section{INTRODUCTION}

Endosymbiosis offers a nutritional advantage to metazoan species in deep-sea hydrothermal vents allowing them to exploit geothermal energy sources (sulphide and methane). Vestimentiferan tubeworms and vesicomyid clams house only thiotrophic sulphur-oxidizing bacterial endosymbionts, which derive their energy from the large amounts of sulphide present in the hydrothermal fluids (Childress \& Fisher, 1992). In contrast, bathymodiolid mussels can host either thiotrophic or methanotrophic symbionts or both simultaneously (for review see FialaMédioni \& Felbeck, 1990; Fisher, 1990). Dual symbioses have been observed in mussels from hydrothermal vents in the Mid-Atlantic Ridge as well as cold seeps in the Barbados accretionary prism and the Gulf of Mexico (Fisher et al., 1993; Distel et al., 1995; Robinson et al., 1998; Pruski et al., 2000). It is postulated that the cooccurrence of two symbiont types provides the host with a greater nutritional flexibility and the possibility to exploit a wider range of ecological niches (Trask et al., 1999). Site-related differences in the relative abundance of thio- and methanotrophic bacteria have been found in one species of mussel from the Mid-Atlantic Ridge (Trask et al., 1999). This suggests that dual symbioses may respond to environmental variations and adjust the relative contribution of both symbiont types.
Whether the association is strictly dependent on thiotrophy or rely on both sulphur-oxidizing and methanotrophic symbionts, the host has to provide large amounts of sulphide to its endosymbionts, while protecting itself against sulphide toxicity (Powell \& Somero, 1986; Somero et al., 1989). As sulphide spontaneously reacts with oxygen, and may therefore lose its energetic interest for the symbionts, the host must avoid sulphide interacting with oxygen before being delivered to the symbionts. Different adaptations to sulphide toxicity have been observed in symbiotic species (Powell \& Somero, 1986). The most common adaptations are the reversible binding of sulphide in the blood of vestimentiferan tubeworms and vesicomyid clams (Arp et al., 1987; Doeller et al., 1988; Childress et al., 1991, 1993) and the oxidation of sulphide to elemental sulphur in vesicomyids (Vetter, 1985) or to thiosulphate in the mitochondria of solemyids (O'Brien \& Vetter, 1990). Although sulphide metabolism has been studied less in mussels, it appears that no sulphidebinding protein is present in their haemolymph and there is yet no evidence of elemental sulphur, a potential storage compound for reduced sulphur, in their tissues (Fisher et al., 1987).

We quantified the main sulphur compounds in Bathymodiolus azoricus Von Cosel, Comtet \& Krylova, 1999, a mussel harbouring a dual symbiosis, in order to determine the specific characteristics of a sulphur-based 
nutrition and examine whether any biochemical differences, potentially related to the relative contribution of the sulphur-oxidizing symbionts, could be observed in specimens collected from two contrasting sites. Special attention was also given to the putative physiological significance of the different sulphur compounds found in this study.

\section{MATERIALS AND METHODS}

\section{Biological samples}

Bathymodiolus azoricus was sampled from two hydrothermal vent-fields (Menez Gwen, $37^{\circ} 51^{\prime} \mathrm{N} \quad 32^{\circ} 31^{\prime} \mathrm{W}$, $850 \mathrm{~m}$ and Lucky Strike, $37^{\circ} 17^{\prime} \mathrm{N} 32^{\circ} 16^{\prime} \mathrm{W}, 1650 \mathrm{~m}$ ) on the Mid-Atlantic Ridge during the DIVA 2 cruise (1994). Mussels were recovered with the French submersible Nautile (IFREMER) in a temperature-insulated box. Gill and mantle tissues were rapidly dissected, frozen and stored in liquid nitrogen until lyophilization and analysis in the laboratory.

\section{Elemental analyses}

Elemental analyses were carried out by the 'Service Central d'Analyses' of CNRS (Montpellier, France). Total sulphur content was measured by inductivity-coupledplasma atomic emission spectrocopy (ICP-AES) and total carbon content was determined using an elemental analyser.

\section{Elemental sulphur quantification}

Elemental sulphur was extracted in chloroform for 20 min (Boulègue, 1978) and the light absorption was measured at $280 \mathrm{~nm}(\varepsilon=826)^{3}$. The detection limit of this method is less than $10 \mu \mathrm{mol} \mathrm{g}^{-1}$ dry weight (DW) (Boulègue, 1978). This method had been used successfully to determine elemental sulphur levels in Calyptogena sp. from deep trenches in subduction zones (Boulègue et al., 1987). However, it is necessary to emphasize that all the sulphur present at a zero oxidation state is extracted and quantified by this method; the discrimination of $\mathrm{S}^{0}$ from polysulphides being therefore impossible. Throughout this paper, all sulphur compounds at an oxidation state of zero are thus referred to as elemental sulphur.

\section{Amino acid extraction and quantification}

Extraction of free amino acids was performed as described in Pruski et al. (1997). Primary amines including the tripeptide glutathione were separated and quantified by reverse phase high performance liquid chromatography (HPLC) after derivatization with ortho-phthaldialdehyde and 2-mercaptoethanol (see Pruski et al., 1998 for a detailed description of the analytical procedure).

\section{Protein quantification}

Frozen tissue samples ( $300 \mathrm{mg})$ were homogenized on ice in $1 \mathrm{ml}$ of extraction buffer $(10 \mathrm{mM}$ Tris $\mathrm{HCl}, 0.5 \mathrm{mM}$ sucrose, $0.15 \mathrm{mM} \mathrm{KCl,} \mathrm{pH} \mathrm{7.6)} \mathrm{supplemented} \mathrm{with} \mathrm{apro-}$ tinin $\left(10 \mu \mathrm{g} \mathrm{ml} \mathrm{m}^{-1}\right)$. Homogenates were sonicated for 2 minutes and centrifuged $\left(6000 \mathrm{~g}\right.$ for $10 \mathrm{~min}$ at $\left.4^{\circ} \mathrm{C}\right)$. Total protein contents of the supernatants were determined with the Bio-Rad protein assay kit using bovine plasma albumin as standard.

\section{Estimation of sulphur content in individual sulphur compounds}

Sulphur incorporated in proteins was estimated after protein quantification using a $1 \%$ protein sulphur content (average sulphur content of proteins ranges from $0.2-$ $2.5 \%$, Javillier \& Bertrand, 1959). The proportion of sulphur in the other compounds was calculated from their respective concentration and the number of sulphur atoms they contain: every compound contains one sulphur atom per molecule, except thiotaurine (two sulphur atoms) and metallothioneins (21 sulphur atoms). The quantity of metallothioneins per gram of dry tissue was deduced from values published in Rousse et al. (1998) using an approximate molecular weight of $15 \mathrm{KDa}$ (two metallothionein isoforms with apparent size of 10 and $20 \mathrm{KDa}$ are present in bathymodiolid mussels, R. Cosson, personal communication).

\section{RESULTS}

Total sulphur contents $\left(\mathrm{S}_{\text {TOTAL }}\right)$ and individual sulphur compound concentrations were highly variable reflecting large differences between individuals, tissues and sampling sites (Table 1).

On average, $\mathrm{S}_{\text {TOTAL }}$ ranged from $1.7-3.1 \%$ of dry tissue with a trend for higher values in samples from Lucky

Table 1. Sulphur content and individual concentrations of a range of sulphur compounds in the tissues of the hydrothermal vent mussel Bathymodiolus azoricus sampled from the Menez Gwen and Lucky Strike sites in the Mid-Atlantic Ridge. Values are expressed in $\mu \mathrm{mol} \mathrm{g}^{-1} d r y$ weight as mean \pm standard deviation $(\mathcal{N}=5)$. Metallothionein concentrations were deduced from values previously published by Rousse et al. (1998).

\begin{tabular}{lccccccccc}
\hline & \multicolumn{2}{c}{$\mathrm{S}_{\text {TOTAL }}$} & $\mathrm{S}^{\circ}$ & Taurine & Hypotaurine & Thiotaurine & Cysteine & Methionine Glutathione & Metallothioneins \\
\hline Menez Gwen & & & & & & & & & \\
Gill & $655 \pm 343$ & $170 \pm 30$ & $152.9 \pm 26.0$ & $34.8 \pm 9.1$ & $16.3 \pm 19.2$ & $30.5 \pm 10.6$ & $0.8 \pm 0.3$ & $2.0 \pm 0.4$ & 0.255 \\
Mantle & $530 \pm 156$ & 0 & $82.7 \pm 11.9$ & $38.3 \pm 11.9$ & $2.0 \pm 0.6$ & $29.5 \pm 4.2$ & $0.7 \pm 0.4$ & $1.4 \pm 0.8$ & 0.056 \\
Lucky Strike & & & & & & & & & \\
Gill & $967 \pm 374$ & $100 \pm 30$ & $96.0 \pm 15.0$ & $28.8 \pm 10.7$ & $62.1 \pm 54.6$ & $12.9 \pm 1.9$ & $1.4 \pm 0.7$ & $2.2 \pm 0.3$ & 0.228 \\
Mantle & $717 \pm 405$ & 0 & $49.1 \pm 13.4$ & $37.2 \pm 5.8$ & $4.1 \pm 2.7$ & $15.2 \pm 4.2$ & $0.7 \pm 0.2$ & $1.8 \pm 0.4$ & 0.099 \\
\hline
\end{tabular}


Table 2. $C / S$ ratios of gill and mantle tissues of Bathymodiolus azoricus and six other deep-sea symbiotic bivalves from hydrothermal vents and cold seeps.

\begin{tabular}{lcc}
\hline & C/S gill & C/S mantle \\
\hline Bathymodiolus azoricus & & \\
$\quad$ Menez Gwen & $18.7^{\mathrm{a}}$ & $26.7^{\mathrm{a}}$ \\
Lucky Strike & $12.2^{\mathrm{a}}$ & $18.1^{\mathrm{a}}$ \\
Bathymodiolus thermophilus & $17^{\mathrm{b}}$ & $34.6^{\mathrm{b}}$ \\
Calyptogena magnifica & $7.3^{\mathrm{b}}$ & $36.5^{\mathrm{b}}$ \\
Calyptogena phaseoliformis & $11.2^{\mathrm{c}}$ & $67^{\mathrm{c}}$ \\
Vesicomya sp. (Barbados) & $3.3^{\mathrm{b}}$ & $39.7^{\mathrm{b}}$ \\
Bathymodiolus boomerang & $29.5^{\mathrm{b}}$ & $48.1^{\mathrm{b}}$ \\
Bathymodiolus $\mathrm{n}$. sp. (Barbados) & $34.3^{\mathrm{b}}$ & $98.2^{\mathrm{b}}$ \\
\hline
\end{tabular}

B. thermophilus, C. magnifica, C phaseoliformis and Vesicomya sp. house sulphur-oxidizing symbionts (Fiala-Médioni \& Métivier 1986, Fiala-Médioni \& Le Pennec 1988, Fisher et al., 1994, Nelson et al., 1995, Pruski et al., 2000); B. boomerang houses sulphuroxidizing and methanotrophic symbionts (Pruski et al., 2000) and Bathymodiolus n. sp. houses methanotrophic symbionts (Pruski et al., 2000). a, this study; b, J. Boulègue, unpublished results; ' , J. Boulègue et al., 1987.

Strike than in those from Menez Gwen (Table 1). $\mathrm{S}_{\text {TOTAL }}$ was typically higher in the symbiont-containing tissues (Table 1).

Values of the carbon/sulphur $(\mathrm{C} / \mathrm{S})$ atom ratio were lower in gills than in mantles (Table 2). Gill $\mathrm{C} / \mathrm{S}$ ratios in Bathymodiolus azoricus were similar to those found in the thiotrophic mussel Bathymodiolus thermophilus Kenk \& Wilson, 1985, higher than those of three vesicomyids from hydrothermal vents and cold seeps and lower than those of two Bathymodiolus species from the Barbados accretionary prism (i.e. Bathymodiolus boomerang Cosel \& Olu, 1998 with both thio- and methanotrophic symbionts and Bathymodiolus sp. with only methanotrophic ones, Table 2).

Elemental sulphur was observed only in the gill tissue and was substantially more abundant in samples from Menez Gwen as compared to those from Lucky Strike $\left(26 \%\right.$ and $10 \%$ of $\mathrm{S}_{\text {TOTAL }}$ for Menez Gwen and Lucky Strike mussels, respectively, Figure 1).

The free sulphur amino acid pool was dominated by taurine $\left(49-153 \mu \mathrm{mol} \mathrm{g}^{-1} \mathrm{DW}\right)$, which was nearly twice as abundant in gills as in mantles, and to a lesser extent by hypotaurine and cysteine (Table 1). Thiotaurine was only found in large amounts in gills and was significantly more abundant in the Lucky Strike mussels (62.1 and $16.3 \mu \mathrm{mol} \mathrm{g}^{-1}$ DW in samples from Lucky Strike and Menez Gwen respectively, Table 1). Levels of free methionine and glutathione were low and fairly constant among tissues and sampling sites (Table 1).

Metallothioneins only accounted for a small proportion of the tissue-sulphur (Figure 1).

Total protein contents were in the range of those reported for shallow mussels $(43 \pm 3 \%$ and $55 \pm 5 \%$ of DW, respectively for gill and mantle tissues of $B$. azoricus). No site-related difference in the protein content was observed. We estimated the amount of sulphur incorporated into proteins to range $1 / 7-1 / 3$ of the total sulphur; mantles having typically higher protein sulphur content than gills (Figure 1).
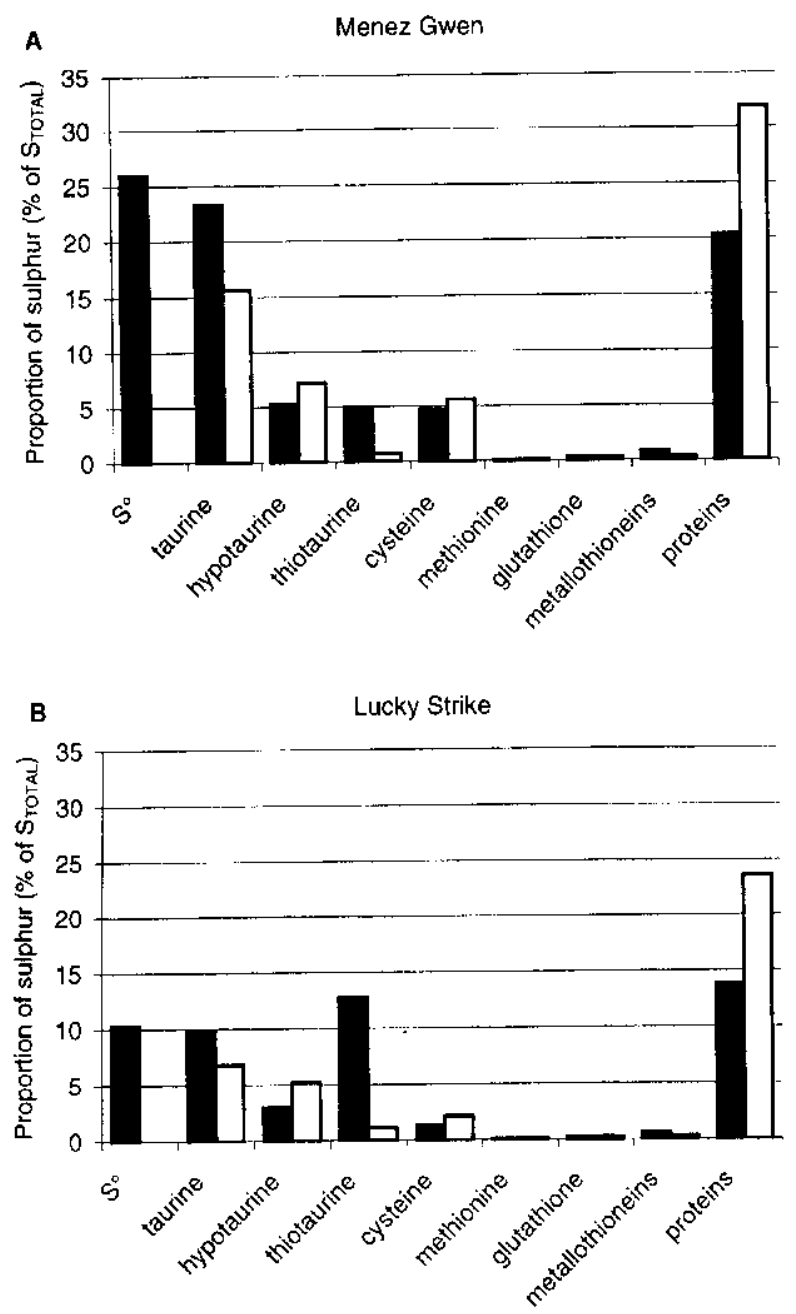

Figure 1. Proportion of sulphur incorporated in a range of sulphur compounds in the tissues of the hydrothermal-vent mussel Bathymodiolus azoricus sampled from the Menez Gwen (A) and Lucky Strike (B) sites in the Mid-Atlantic Ridge. Values are expressed as \% of $\mathrm{S}_{\text {TOTAL }}(\mathrm{N}=5)$, black bars $=$ gill, white bars $=$ mantle. Every compound contains 1 atom of sulphur per molecule, except thiotaurine (2 atoms of sulphur) and metallothioneins (21 atoms of sulphur). The proportion of sulphur incorporated to proteins was estimated using a $1 \%$ protein sulphur content (average sulphur content of proteins ranges from $0.2-2.5 \%$, Javillier \& Bertrand, 1959) and protein contents of 43 and $55 \%$ DW, respectively in gill and mantle (see results).

The proportion of unidentified sulphur compounds was higher in mantles than in gills especially in samples from Lucky Strike (respectively in gills and mantles 14\% and $38 \%$ of $\mathrm{S}_{\text {TOTAL }}$ in Menez Gwen mussels, and 48 and 61\% in Lucky Strike mussels).

\section{DISCUSSION}

To date a dual symbiosis has been observed in the two species of Bathymodiolus sampled from the Mid-Atlantic Ridge (Fiala-Médioni et al., 1986; Distel et al., 1995; Robinson et al., 1998; Pruski et al., 2000; A. FialaMédioni, unpublished data). Both sulphur-oxidizing and methanotrophic bacteria are localized in a single type of host cells (i.e. the bacteriocytes) and contribute to the overall nutrition of their host (Trask et al., 1999). 
However, based on the lack of stimulation of carbon fixation by thiosulfate in some species of Bathymodiolus, the nutritional importance of the sulphur-oxidizing symbionts in these dual symbioses has been questioned (Cavanaugh et al., 1992). As environmental differences in the chemistry of the surrounding water could potentially modify the relative contribution of the two types of symbionts, and thus their biochemical signature in the tissues, we compared the sulphur compound composition of B. azoricus in samples collected from two contrasting sites (Menez Gwen and Lucky Strike).

Total sulphur content in mantles of B. azoricus was in the range of those reported for symbiont-free marine organisms, while gills were enriched in sulphur (i.e. sulphur content of marine animals ranges from 0.45 to $2.8 \%$, average values being $0.89 \%$, Kaplan et al., 1963). A high sulphur content in symbiont-containing tissues is a common feature of species relying on thiotrophic endosymbionts for their nutrition (Vetter \& Fry, 1998) and can be explained easily by both high environmental sulphur concentrations and the utilization of sulphide by sulphuroxidizing symbionts. However, a strong enrichment in sulphur was observed in gills of the sulphur-oxidizing symbiont-bearing vesicomyids, Calyptogena magnifica Boss \& Turner, 1980, Calyptogena phaseoliformis Métivier, Okutani \& Ohta, 1986 and a non-described species from the Barbados accretionary prism (gill ratios in these three species correspond respectively to $1 / 5,1 / 6$ and $1 / 12$ of mantle values). The $\mathrm{C} / \mathrm{S}$ atom ratio in $B$. azoricus indicates a low sulphur enrichment of the gill tissue compared to the mantle (Table 2). Nevertheless, these values are comparable to those found in the thiotrophic mussel B. thermophilus and are therefore consistent with a nutrition based, at least partly, on sulphur-oxidizing endosymbionts (Table 2). Interestingly, gills of vesicomyids always display higher sulphur enrichment than gills of thiotrophic mussels. This may be partly attributable to differences in the chemical composition of their respective environment (e. g. sulphide levels), but it may also be explained by different sulphide uptake mechanisms: vesicomyids actively concentrate sulphide from the environment using a blood component (Childress et al., 1991; 1993), whereas in mussels, which are more passive, sulphide penetrates by simple diffusion (Childress \& Fisher, 1992).

Elemental sulphur was found in a wide variety of animals, including several species from hydrothermal vents (for review see Somero et al., 1989; Vetter \& Fry, 1998), but was never observed in species of Bathymodiolus (e.g. B. thermophilus did not contain elemental sulphur, Fisher et al., 1987; Vetter \& Fry, 1998). Nevertheless, our results indicate that a large proportion of the gill sulphur is at a zero oxidation state in B. azoricus (Table 1), which strongly suggests the occurrence of elemental sulphur $\left(\mathrm{S}^{0}\right)$. Those high levels of $\mathrm{S}^{0}$ are in the range of those reported for thiotrophic species such as the vesicomyid Calyptogena phaseoliformis (Boulègue et al., 1987) and the lucinid Lucinoma annulata Reeve, 1850 (Vetter, 1985). Microanalyses of $B$. thermophilus gill have only demonstrated the accumulation of sulphur in lysosomes and to a lesser extent in the bacteria (Chassard-Bouchaud et al., 1988). The high amounts of $\mathrm{S}^{0}$ found in gills of B. azoricus may thus represent polar chains of polysulphides that have precipitated in the cytoplasm of the bacteriocytes in the nanometric orthorhombic form S8 as suggested for Riftia pachyptila Jones, 1981 (Truchet et al., 1998). Other compounds such as polythionates $\mathrm{Sn}$ (SO3)22- or organopolysulphides R-Sn-R, which are commonly produced by sulphur-oxidizing Thiobacilli and phototrophic sulphur bacteria (Hazeu et al., 1988; Durand et al., 1994; Prange et al., 1999), could have been extracted and quantified by the method we used. Hence, these compounds could putatively account for some of the elemental sulphur found in B. azoricus. However, these compounds have thus far never been observed in thiotrophic symbioses. The amount of $S^{0}$ in field specimens represent a balance between exposure to H2S and metabolic consumption of the resulting $\mathrm{S}^{0}$ (Vetter \& Fry, 1985). As geochemical data indicate that the sulphide level at Menez Gwen is lower than at Lucky Strike (Charlou et al., 1996), the higher elemental sulphur content in the Menez Gwen mussels suggests a lower $\mathrm{S}^{0}$ consumption, which could reflect a low sulphide-oxidizing activity.

When $\mathrm{S}^{0}$ content is subtracted from $\mathrm{S}_{\mathrm{TOTAL}}$, the amount of sulphur in symbiont-containing tissues are not significantly different from values in mantles, where sulphur is likely to be found in compounds playing no specific function in sulphide metabolism (e.g. free and protein amino acids, sulphated mucopolysaccharides and sulpholipids). Our results indicate that a large proportion of the sulphur was indeed contained in free sulphur amino acids under a reduced form (cysteine, methionine and the sulphydryl group of thiotaurine) or an oxidized form (taurine, hypotaurine and the inner sulphur of thiotaurine). Taurine was, by far, the dominant sulphur-containing amino acid in all tissues. A high concentration of this compound is a common feature in non-symbiotic bivalves where taurine is one of the main effectors for osmoregulation (Awapara, 1962; Campbell \& Bishop, 1970; Bishop et al., 1983). Specific functions related to the symbiotic mode of life have been also attributed to taurine, which could be a sink for sulphur and a nitrogen storage compound as well (Conway \& MacDowell Capuzzo, 1992; Lee et al., 1997). The co-occurrence of the two unusual amino acids, hypotaurine and thiotaurine, is a specific feature in deep-sea thiotrophic symbioses (for review see Pruski et al., 2000), where these compounds may be involved in the transfer of reduced sulphur from the host to the symbionts. Moreover, as thiotaurine contains one atom of sulphur at a reduced state (-II), it may represent a non-toxic storage compound for reduced sulphur until its oxidation by the sulphuroxidizing symbionts. It was in fact previously observed in two species of Bathymodiolus (Bathymodiolus brevior Cosel, Métivier \& Hashimoto, 1994 and Bathymodiolus elongatus Cosel, Métivier \& Hashimoto, 1994) from the Lau Basin that the level of this thio-amine decreased in specimens sampled from declining sites (Pranal et al., 1995). The lower thiotaurine concentration in the gills of the Menez Gwen mussels, together with their higher elemental sulphur content suggest therefore a lower reliance on thiotrophic symbionts in the Menez Gwen mussels. This is consistent with evidence from bacterial counts in gills indicating a higher relative abundance of methanotrophic symbionts in specimens from Menez Gwen as compared to those from Lucky Strike (A. Fiala-Médioni, unpublished data) and geochemical data indicating higher methane content in Menez Gwen fluids (Charlou et al., 
2000). This study also reported higher concentrations of sulphide at Lucky Strike, which can explain the higher $\mathrm{S}_{\text {TOTAL values in samples from this site. }}$

Protein sulphur is usually the dominant form of sulphur in animals. It indeed represents an important proportion of the total sulphur content in both tissues (Figure 1). In the mantle, which is involved in the storage of proteins and glycogen (Gabbott, 1983), protein sulphur accounted, as expected, for a larger proportion of the total sulphur content $\left(1 / 4-1 / 3\right.$ of $\left.\mathrm{S}_{\mathrm{TOTAL}}\right)$ than in the gill $(1 / 7-1 / 5$ of $\mathrm{S}_{\mathrm{TOTAL}}$, Figure 1). Other organic compounds such as sulphated mucopolysaccharides are typically secreted in the mantle of bivalves (Garcia-Gasca et al., 1994) and could account for a non-negligible proportion of the sulphur in this tissue. Some specific proteins, such as metallothioneins, are known to have a high sulphur content (21 S atoms per molecule, Stillman, 1995) and have been proposed to play a role in thiosulphate transport in Bathymodiolus spp. (Rousse, 1999). However, metallothioneins only accounted for a small proportion of the tissue-sulphur in B. azoricus and are thus unlikely to be of prime importance for sulphur metabolism (Figure 1).

Considering the specific characteristics of organisms from high sulphide environments, which possess a sulphide-oxidizing peripheral barrier (Powell \& Somero, 1986), inorganic oxidized sulphur products $\left(\mathrm{S}_{2} \mathrm{O}_{3}{ }^{2-}\right.$, $\left.\mathrm{SO}_{4}{ }^{2-}, \mathrm{Sn}^{2-}\right)$ are certainly present in $B$. azoricus tissues. These inorganic sulphur compounds are probably more abundant in gills than in mantles. This was demonstrated for $B$. thermophilus where the lower thiosulphate levels found in the mantle may be explained by the lower activity of the sulphide-oxidizing barrier in this tissue (Fisher et al., 1988).

In summary, most of the sulphur contained in the tissues of $B$. azoricus is incorporated in common organic compounds. However, the sulphur enrichment of the gill of this mussel and the occurrence of specific sulphur compounds, such as elemental sulphur and thiotaurine, are consistent with a nutrition partly based on sulphuroxidizing symbionts. Our results furthermore suggest that mussels from Lucky Strike are more dependent on thiotrophy as compared to specimens from Menez Gwen.

As Bathymodiolus-like species do not possess specific proteins allowing them to concentrate and store sulphur on a non-toxic form, sulphur storage compounds such as elemental sulphur and thiotaurine may be important to support the activity of the bacterial sulphur-oxidizing symbionts during short time periods where sulphide availability in the environment is reduced.

We thank the captain and the crew of the Nadir, the crew and pilots of the Nautile, the chief scientist A.M. Alayse and the scientific team for their help during the DIVA 2 cruise. J.C. Colomines is gratefully acknowledged for his technical assistance during HPLC analyses. This work was supported by UMR 7621 CNRS and the EC MAST AMORES program (MAST 3-CT.950040).

\section{REFERENCES}

Arp, A.J., Childress, J.J. \& Vetter, R.D., 1987. The sulphidebinding protein in the blood of the vestimentiferan tubeworm, Riftia pachyptila, is the extracellular hemoglobin. Fournal of Experimental Biology, 128, 139-158.
Awapara, J., 1962. Free amino acids in invertebrates: a comparative study of their distribution and metabolism. In Amino acid pools (ed. T. Holden), pp. 158-175. New York: Elsevier.

Bishop, S.H., Ellis, L.L. \& Burcham, J.M., 1983. Amino acid metabolism. In The Mollusca, vol. 1, Metabolic biochemistry and molecular biomechanics (ed. K.M. Wilbur), pp. 244-328. New York: Academic Press.

Boulègue, J., 1978. Solubility of elemental sulfur in Water at 398K. Phosphorus and Sulphur, 5, 127-128.

Boulègue, J., Bénedetti, E.L., Dron, D., Mariotti, A. \& Létolle, R., 1987. Geochemical and biogeochemical observations on the biological communities associated with fluid venting in Nankai Trough and Japan Trench subduction zones. Earth and Planetary Science Letters, 83, 343-355.

Campbell, J.W. \& Bishop, S.H., 1970. Nitrogen metabolism in molluscs. In Comparative biochemistry of nitrogen metabolism. 1. The invertebrates (ed. J.W. Campbell), pp. 103-205. London: Academic Press.

Cavanaugh, C.M., Levering, P.R., Maki, J.S., Mitchell, R. \& Lidstrom, M.E., 1992. Evidence for methylotrophic symbionts in a hydrothermal vent mussel (Bivalvia: Mytilidae) from the Mid-Atlantic Ridge. Applied and Environmental Microbiology, 58, 3799-3803.

Chassard-Bouchaud, C. et al., 1988. Microanalysis as applied to hydrothermal vent biological communities. Preliminary data perspectives. In Proceedings of the symposium 'Hydrothermal vents of the East Pacific Rise: Biology and Ecology', Paris (France), 4-7 November 1985 (ed. L. Laubier), pp. 203-218. Oceanologica Acta, Hors série no. 8.

Charlou, J.L. et al., 1996. Methane degassing, hydrothermal activity and serpentinization between the fifteen-twenty Fracture Zone area and the Azores Triple junction (Mid Atlantic Ridge). Fournal of Conference Abstracts, 1, 771-772.

Charlou, J.L., Donval, J.P., Douville, E., Jean-Baptise, P., Radford-Knoery, J., Fouquet, Y., Dapoigny, A. \& Stiernard, M., 2000. Compared geochemical signatures and the evolution of Menez Gwen $\left(3750^{\prime} \mathrm{N}\right)$ and Lucky Strike $\left(3717^{\prime} \mathrm{N}\right)$ hydrothermal fluids, south of the Azores Triple Junction on the Mid-Atlantic Ridge. Chemical Geology, 171, 49-75.

Childress, J.J. \& Fisher, C.R., 1992. The biology of hydrothermal vent animals: physiology, biochemistry, and autotrophic symbiosis. Oceanography and Marine Biology: an Annual Review, 30, 337-441.

Childress, J.J., Fisher, C.R., Favuzzi, J.A., Arp, A.J. \& Oros, D.R., 1993. The role of a zinc-based, serum-borne sulphidebinding component in the uptake and transport of dissolved sulphide by the chemoautotrophic symbiont-containing clam Calyptogena elongata. Fournal of Experimental Biology, 179, 131-158.

Childress, J.J., Fisher, G.R., Favuzzi, J.A. \& Sanders, N.K., 1991. Sulfide and carbon dioxide uptake by the hydrothermal vent clam, Calyptogena magnifica, and its chemoautotrophic symbionts. Physiological Zoology, 64, 1444-1470.

Conway, N.M. \& McDowell Capuzzo, J.E., 1992. High taurine levels in the Solemya velum symbiosis. Comperative Biochemistry and Physiology, 102B, 175-185.

Distel, D.L., Lee, H.K.-W. \& Cavanaugh, C.M., 1995. Intracellular coexistence of methano- and thioautotrophic bacteria in a hydrothermal vent mussel. Proceedings of the National Academy of Sciences of the United States, 92, 9598-9602.

Doeller, J.E., Kraus, D.W., Colacino, J.M. \& Wittenberg, J.B., 1988. Gill haemoglobin may deliver sulfide to bacterial symbionts of Solemya velum (Bivalvia, Mollusca). Biological Bulletin, Woods Hole Laboratory, 175, 388-396.

Durand, P., Benyagoub, A. \& Prieur, D., 1994. Numerical taxonomy of heterotrophic sulfur-oxidizing bacteria isolated from southwestern Pacific hydrothermal vents. Canadian Fournal of Microbiology, 40, 696-697. 
Fiala-Médioni, A. \& Felbeck, H., 1990. Autotrophic process in invertebrate nutrition: bacterial symbiosis in bivalve molluscs. In Animal nutrition and transport processes, 1, Nutrition in wild and domestics animals, Comparative Physiology, vol. 5 (ed. J. Mellinger), pp. 49-59. Basel: Karger Verlag.

Fiala-Médioni, A., Herry, A. \& Le Pennec, M., 1986. Ultrastructure of the gill of the hydrothermal-vent mytilid Bathymodiolus sp. Marine Biology, 92, 65-72.

Fiala-Médioni, A. \& Le Pennec, M., 1988. Structural adaptations in the gill of the Japanese subduction zone bivalves (Vesicomyidae) Calyptogena phaseoliformis and Calyptogena laubieri. Oceanologica Acta, 11, 185-192.

Fiala-Médioni, A. \& Métivier, C., 1986. Ultrastructure of the gill of the hydrothermal-vent bivalve Calyptogena magnifica, with a discussion of its nutrition. Marine Biology, 92, 65-72.

Fisher, C.R., 1990. Chemoautotrophic and methanotrophic symbioses in marine invertebrates. Reviews in Aquatic Sciences, 2, 399-436.

Fisher, C.R., Brooks, J.M., Vodenichar, J.S., Zande, J.M., Childress, J.J. \& Burke, R.A. Jr, 1993. The co-occurrence of methanotrophic and chemoautotrophic sulfur-oxidising bacterial symbionts in a deep-sea mussel. Marine Ecology Progress Series, 14, 277-289.

Fisher, G.R. et al., 1988. Microhabitat variation in the hydrothermal vent mussel, Bathymodiolus thermophilus, at the Rose Garden vent on the Galapagos Rift. Deep-Sea Research, 35, 1769-1791.

Fisher, C.R., Childress, J.J., Oremland, R.S. \& Bidigare, R.R., 1987. The importance of methane and thiosulfate in the metabolism of bacterial symbionts of two deep-sea mussels. Marine Biology, 96, 59-71.

Fisher, C.R., Childress, J.J., Macko, S.A. \& Brooks, J.M., 1994. Nutritional interactions in Galapagos Rift hydrothermal vent communities: Inferences from stable carbon and nitrogen isotope analyses. Marine Ecology Progress Series, 103, 45-55.

Gabbott, P.A., 1983. Developmental and seasonal metabolic activities in marine molluscs. In The Mollusca, vol. 2: Environmental biochemistry and physiology (ed. P.W. Hochachka), pp. 165-217. New York: Academic Press.

Garcia-Gasca, A., Ochoa-Baez, R.I. \& Betancourt, M., 1994. Microscopic anatomy of the mantle of the pera oyster Pinctada mazatlanica (Hanley, 1856). Journal of Shellish Research, 13, 85-91.

Hazeu, W., Steudel, R., Batenburg-van de Vegte, W.H., Bos, P. \& Kuenen, J.G., 1988. Elemental sulfur as an intermediate in the oxidation of reduced sulphur compounds by Thiobacillus ferrooxidans: localization and characterization. In Biohydrometallurgy: Proceedings of the International Symposium, Warwick 1987 (ed. P.R. Norris and D.P. Kelly), pp. 111-118. Kew Surrey (UK): Antony Rowe Ltd, Science and Technology Letters.

Javillier, M. \& Bertrand, D., 1959. La composition élémentaire des organismes. In Composition chimique des organismes, Tome I, Composition chimique des organismes, pp. 9-84. Paris: Masson \& Cie ed.

Kaplan, I.R., Emery, K.O. \& Rittenberg, S.C., 1963. The distribution and isotopic abundance of sulphur in recent marine sediments off southern California. Geochimica et Cosmochimica Acta, 27, 297-331.

Lee, R.W., Childress, J.J. \& Desaulniers, N.T., 1997. The effects of exposure to ammonia on ammonia and taurine pools of the symbiotic clam Solemya reidi. Fournal of Experimental Biology, 200, 2797-2805.

O’Brien, J. \& Vetter, R.D., 1990. Production of thiosulfate during sulphide oxydation by mitochondria of the symbiontcontaining bivalve Solemya reidi. Fournal of Experimental Biology, 149, 133-148.
Nelson, D.G., Hagen, K.D. \& Edwards, D.B., 1995. The gill symbiont of the hydrothermal vent mussel Bathymodiolus thermophilus is a psychrophilic, chemoautotrophic, sulfur bacterium. Marine Biology, 121, 487-495.

Powell, M.A. \& Somero, G.N., 1986. Adaptations to sulfide by hydrothermal vent animals: sites and mechanisms of detoxification and metabolism. Biological Bulletin, 171, 274-290.

Pranal, V., Fiala-Médioni, A. \& Colomines, J.C., 1995. Amino acid and related compound composition in two symbiotic mytilid species from hydrothermal vents. Marine Ecology Progress Series, 119, 155-166.

Prange, A. et al., 1999. In situ analysis of sulfur in the sulfur globules of phototrophic sulfur bacteria by X-ray absorption near edge spectroscopy. Biochimica et Biophysica Acta, 11428, 446-454.

Pruski, A.M., Fiala-Médioni, A. \& Colomines, J.C., 1997. High amounts of sulphur-amino acids in three symbiotic mytilid bivalves from deep benthic communities. Comptes Rendus de l'Académie des Sciences, Série 3: Sciences de la Vie, 320, 791-796.

Pruski, A.M., Fiala-Médioni, A., Boulègue, J. \& Colomines, J.C., 1998. Sulphur-amino acids in symbiotic species from hydrothermal vents and cold seeps. Cahiers de Biologie Marine, 39, 321-324.

Pruski, A.M., Fiala-Médioni, A., Prodon, R. \& Colomines, J.-G., 2000. Thiotaurine is a biomarker of sulfide-based symbiosis in deep-sea bivalves. Limnology and Oceanography, 45, 1860-1867.

Robinson, J.J., Polz, M.F., Fiala-Médioni, A. \& Cavanaugh, C.M., 1998. Physiological and immunological evidence for two distinct $\mathrm{C} \operatorname{sub}(1)$-utilizing pathways in Bathymodiolus puteoserpentis (Bivalvia: Mytilidae), a dual endosymbiotic mussel from the Mid-Atlantic Ridge. Marine Biology, 132, 625-633.

Rousse, N., Boulègue, J., Cosson, R.P. \& Fiala-Médioni, A., 1998. Bioaccumulation des métaux chez le mytilidae hydrothermal Bathymodiolus sp. de la ride médio-Atlantique. Oceanologica Acta, 21, 597-607.

Rousse, N., 1999. La bioaccumulation des métaux et les procédés de détoxication chez le mollusque bivalve symbiotique dépendant de la chimiosynthèse, Bathymodiolus sp. PhD thesis, Université Pierre et Marie Curie, Paris, France.

Somero, G.N., Anderson, A.E. \& Childress, J.J., 1989. Transport, metabolism and detoxification of hydrogen sulfide in animals from sulfide rich-environments. Reviews in Aquatic Sciences, 1, 591-614.

Stillman, M.J., 1995. Metallothioneins. Coordination Chemistry Revieres, 144, 461-511.

Trask, J.L. \& Van Dover, C.L., 1999. Site-specific and ontogenic variations in nutrition of mussels (Bathymodiolus sp.) from the Lucky Strike hydrothermal vent field, Mid-Atlantic Ridge. Limnology and Oceanography, 44, 334-343.

Truchet, M., Ballan-Dufrançais, G., Jeantet, A.-Y., Lechaire, J.P. \& Cosson, R., 1998. Le trophosome de Riftia pachyptila et Ternia jerichonana (Vestimentifera): bioaccumulations métalliques et métabolisme du soufre. Cahiers de Biology Marine, 39, 129-141.

Vetter, R.D., 1985. Elemental sulfur in the gills of three species of clams containing chemoautotrophic symbiotic bacteria: a possible inorganic energy storage compound. Marine Biology, 88, 33-42.

Vetter, R.D. \& Fry, B., 1998. Sulfur contents and sulfur-isotope compositions of thiotrophic symbioses in bivalve molluscs and vestimentiferan worms. Marine Biology, 132, 453-460.

Submitted 29 November 2001. Accepted 4 March 2002 